\title{
Transcription Tables
}

Several conventions are applied: I. omission of the word-initial glottal stop (e.g., al-șawt for 'al-şawt, $A b \bar{u}$ for 'Abū) except in the context of recited Qur'anic Arabic; 2. indication of the elision of the glottal stop of the definite article (e.g., fī l-bayt for fī al-bayt); 3 . in titles, proper names, and uncontextualized phrases the definite article is transcribed al (e.g., șifät al-huruf for șifātu l-ḥurūf and Labīb al-Sa'ìd for Labỉbu l-Sa'ìd; 4. the tä marbūtah (at) in construct is transcribed at: otherwise it is transcribed $a h$ (e.g., sūrat al-Baqarah for sūrah al-Baqarah, al-majallah al-mūsiqiyyah for al-majallatu 1-mūsiqqiyyah); 5 . in spoken Egyptian Arabic the $a h$ of the $t \bar{a}^{3}$ marbuttah is transcribed $a$ (e.g., nagama for nagiamah).

Words that have a certain frequency in English (Qur'an, Ramadan, al-Azhar, Mohammad) are not given diacritics except in the context of quotations transcribed from Arabic. Further, the names of Arab authors published in Western languages are spelled as they appear in their respective publications.

Table I applies to all literary references and to proper names. Tables I and 2 reflect the sound of recited Quranic Arabic. Tables I and 3 reflect spoken Egyptian Arabic. The transcription of interviews and comments often reflects the speaker's mixing of literary and colloquial pronunciations. Also, transcriptions of both recited Qur'anic Arabic and spoken Egyptian Arabic show the elision of the /l/ of the definite article (e.g., aș-șawt and iș-șōt, respectively). 
Table 1. Transliteration of Literary References and Proper Names

\begin{tabular}{|c|c|c|c|c|c|c|c|}
\hline ? & c & $z$ & j & q ق q & & $\mathrm{i}$ & $\bar{T}$ \\
\hline b & 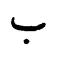 & $\mathrm{s}$ & س & k ك & & $\mathrm{u}$ & $\underline{-}$ \\
\hline $\mathbf{t}$ & $=$ & $\check{s}$ & ش & $1 \mathrm{~J}$ & & $\bar{a}$ & L \\
\hline$\underline{t}$ & $\bullet$ & $\mathbf{s}$ & $ص$ & $m p$ & & $\overline{\mathbf{i}}$ & ل \\
\hline j & ج & $\mathrm{d}$ & ض & n ن & & $\overline{\mathrm{u}}$ & 2 \\
\hline h & $\tau$ & $t$ & $b$ & $\mathrm{~h}$. & & ay & كَي \\
\hline $\mathbf{x}$ & $\dot{\tau}$ & 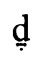 & b & w & & aw & ك- \\
\hline d & נ & c & $\varepsilon$ & y & & 'à & $T$ \\
\hline$\underline{\mathrm{d}}$ & j & $\dot{\mathrm{g}}$ & $\dot{\varepsilon}$ & $\mathrm{ah} / \mathrm{at}$ & z & & \\
\hline $\mathbf{r}$ & $\jmath$ & f & ف & a 1 & & & \\
\hline
\end{tabular}

Table 2. Transliteration of Recited Qur'anic Arabic

Table 1 plus the following:

r single tap $/ \mathrm{r} /$, unrolled $/ \mathrm{r} /$

m nasalization (g்hunnah)

ž voiced, dorso-alveolar spirant

a schwa

a low, back, slightly rounded vowel

() partial assimilation

1 pharyngealized /1/

$\overline{\mathrm{e}}$ medium high, medium front vowel

Table 3. Transliteration of Spoken Egyptian Arabic

Table 1 plus the following:

$\overline{\mathrm{e}} \quad$ medium high, medium front vowel

o middle, moderately rounded, back vowel

g voiced palative stop

$z$ pharyngealized / $z$ /

1 pharyngealized /1/ 